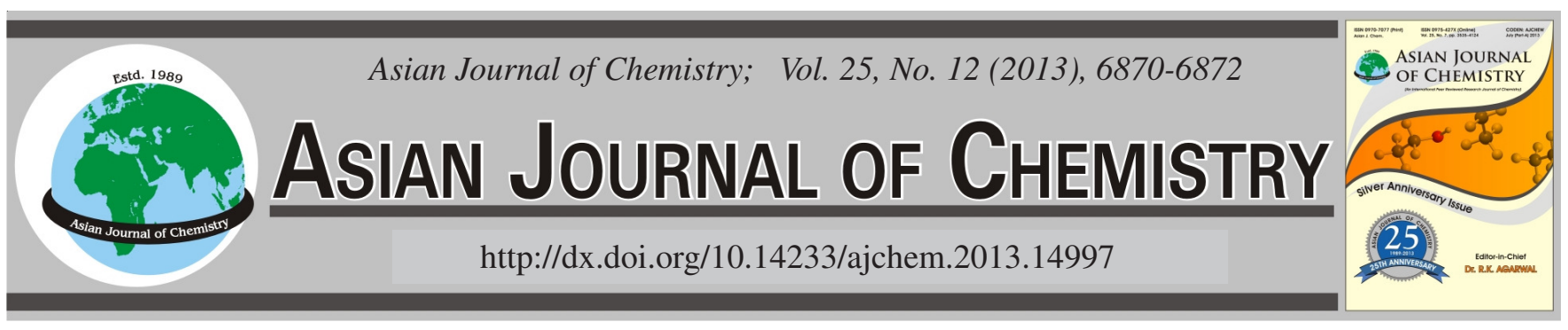

\title{
Determination of the Antioxidant Vitamin Levels in Fresh and Dried Bee Pollens in Bingol's Flora
}

\author{
Naci Ömer Alayunt ${ }^{1}$, Yusuf Karagözoglu ${ }^{2}$, AkIf Evren Parlak $^{3}$ and Semra Türkoglu,*
}

\begin{abstract}
${ }^{1}$ Department of Chemistry, Faculty of Science and Arts, Firat University, Elazig, Turkey
${ }^{2}$ Department of Chemistry, Faculty of Science and Arts, Bingol University, Bingol, Turkey

${ }^{3}$ Firat University, Keban Vocational School of Higher Education, Elazig, Turkey

${ }^{4}$ Department of Food Engineering, Faculty of Engineering, Tunceli University, Tunceli, Turkey
\end{abstract}

*Corresponding author: E-mail: smrturkoglu@ hotmail.com

In this study, fresh pollens collected from Bingol, province in Turkey were analyzed in June and the dried pollens stored by being kept in a cool, dark place for 8 months at room temperature were analyzed again in February. It was determined that, during this time, there was the maximum loss in the group Adakli with $68.23 \%$ in terms of vitamin A, in the group Gökdere with $70.60 \%$ in terms of vitamin E, in the group Adakli with $71.01 \%$ in terms of vitamin C. These results obtained about the values of vitamin may vary depending on the geographic location where the pollen grows up, the season in which it is gathered and its drying and storage conditions.

Key Words: Bee pollen, Antioxidant vitamins, Bingol.

\section{INTRODUCTION}

Bee pollen has been used for many years in both traditional medicine and supplementary nutrition, as well as in alternative diets, mainly due to its nutritional properties and health benefits ${ }^{1-3}$. Its nutritional composition consists of proteins, lipids, sugars, fibers, mineral salts (calcium, chlorine, copper, iron, magnesium, iodine, molybdenum, selenium, strontium, tin, boron, fluoride, vanadium, chromium, phosphorus, potassium, sulfur, aluminum, iron, manganese and zinc), amino acids and vitamins (A, B, C, D, E ) ${ }^{4,5}$.

The bee pollen contains proteins, carbohydrates, lipids and minerals in its compounds. It also contains the antioxidant vitamins (vitamins $\mathrm{C}, \mathrm{E}$ and $\beta$-carotene, as pro-vitamin $\mathrm{A}$ ), those from $\mathrm{B}$ complex and vitamin $\mathrm{D}^{6,7}$.

Reactive oxygen species (ROS) are produced in all mammalian cells as the result of normal cellular metabolism and due to the activation of oxidant-producing enzymes in response to exogenous stimulus. The balance between reactive oxygen species production and antioxidant defenses determines the degree of oxidative stress. Generation of reactive oxygen species has been associated with cell signaling, stress responses, cell proliferation, aging and cancer development. The ability of reactive oxygen species to induce cellular damage and to cause cell death gives the possibility to utilize this property in the treatment of cancer through a free radical mediated mechanism ${ }^{8}$. It has been reported that both pollen and propolis extracts and their compounds which have free radical scavenging activity were isolated ${ }^{9,10}$.

Free radicals and other reactive oxygen species (ROS) are generated by all aerobic cells and are known to participate in a wide variety of deleterious reactions ${ }^{11}$. In normal conditions aerobic organisms are protected against oxidative damage by a variety of antioxidant systems. The antioxidant system is divided into two groups as enzymatic and nonenzymatic. Nonenzymatic antioxidant system which consists of vitamin A, E, C and Se, has shown to react with organic free radicals and protect biomembranes ${ }^{12}$.

In present study, it is aimed to compare the differences of antioxidant vitamin levels between fresh and dried bee pollen collected from five different locations of Bingöl in Turkey; Gökdere Village bounded to the city center (altitude 1565), Adakli town center (altitude 1500), Sirnan village bounded to Adakli (altitude 1810), Karliova town center (altitude 1940), the vicinity of Kanires in the center of Karliova (altitude 19402000). Analysis of antioxidant vitamin levels in samples of bee pollen was determined by high pressure liquid chromatography. In this study, collected fresh pollens were analyzed in June and the dried pollens stored by being kept in a cool, dark place for eight months at room temperature were analyzed again in February. This is an important study because as far as we know it is the first time that this bak hive producted in Bingol is examined and this study might help to increase its economic benefit. 


\section{EXPERIMENTAL}

Sample preparation: Thirty samples of fresh pollen were collected from Bingol on June, 2011. Fifteen hives of bees Apis mellifera were used. In this study, each sample was homogenized in order to bak withdraw $200 \mathrm{~g}$ of fresh pollen to be sent to the laboratory. These samples were stored for 8 months at $+4{ }^{\circ} \mathrm{C}$, but these were protected from light exposure by using aluminum foil and tests were analyzed by HPLC. Pollen samples were kept at plastic bags until the vitamin quantification.

\section{Antioxidant vitamin analysis}

Extraction of vitamin A: Vitamin A was extracted by the method described by Amin and Cheah ${ }^{13}$ and Abdulnabi et al..$^{14}$ with slightly modification. $40 \mathrm{~mL}$ of $95 \%$ ethanol was added to $5 \mathrm{~g}$ sample and $10 \mathrm{~mL}$ of $100 \%$ (w/v) potassium hydroxide was added to the last mixture and homogenized for $3 \mathrm{~min}$. The mixture was saponified by means of a refluxing apparatus and heated using an electric heating mantle for $0.5 \mathrm{~h}$ and then cooled to room temperature. The mixture was frequently agitated to avoid any aggregation. For the extraction step, the mixture was transferred into separation funnel and $50 \mathrm{~mL} n$-hexane was added. The funnel was inverted, vented and then shaken vigorously for a few seconds and the layer was allowed to separate. The upper layer (hexane extract) was pipette out and the aqueous layer was re-extracted twice, each time with $50 \mathrm{~mL}$ of $n$-hexane. Then, the upper layer was pooled and washed with distilled water until free of alkali. The extract was then filtered through anhydrous sodium sulphate to remove any water residue. The hexane residues were removed under reduced pressure at $45^{\circ} \mathrm{C}$ using rotary evaporator. The resulting extract was diluted to $10 \mathrm{~mL}$ with HPLC grade-hexane. Samples were carried out in five-replicates.

Extraction of vitamin C: Vitamin $\mathrm{C}$ was extracted accordingly to the combination of method of Amin and Cheah ${ }^{13}$ and Abdulnabi et al. ${ }^{14}$ with slightly modification. $5 \mathrm{~g}$ sample was added with $50 \mathrm{~mL}$ of $2 \%$ metaphosphoric acid. The mixture was placed in a conical flask (wrapped with aluminium foil) and agitated at $100 \mathrm{rpm}$ with the aid of an orbital shaker for $15 \mathrm{~min}$ at room temperature. The mixture was then filtered through a Whatman No. 4 filter paper to obtain a clear extract. The ratio of the sample to extraction solution was 1:1 sample was extracted three times.

Analysis of vitamin E: Vitamin E was extracted according to the method of Amin and Cheah ${ }^{13}$ and Abdulnabi et al. ${ }^{14}$ with slightly modification. $20 \mathrm{~mL}$ methanol was added to $5 \mathrm{~g}$ sample. The mixture was mixed with $60 \mathrm{~mL} \mathrm{CCl} 4: \mathrm{CH}_{3} \mathrm{OH}$ mixture (3:1) and agitated at $100 \mathrm{rpm}$ with the aid of an orbital shaker for $20 \mathrm{~min}$. The $\mathrm{CCl}_{4}$ fraction was separated from the aqueous phase in a separatory funnel and dried over $\mathrm{Na}_{2} \mathrm{SO}_{4}$. The filtrate was evaporated until it was dry under pressure $45{ }^{\circ} \mathrm{C}$ using rotary evaporator. The extract lipid fraction was saponified by refluxing with $4 \mathrm{~mL}$ of $30 \%$ methanolic $\mathrm{KOH}$ for $0.5 \mathrm{~h}$ at the boiling point of methanol in the presence of $0.5 \mathrm{~g}$ ascorbic acid. After the flask was cooled at room temperature, $15 \mathrm{~mL}$ of salted water was added and the analogues of tocopherol were extracted twice with $40 \mathrm{~mL}$ petroleum ether in a separator funnel. The ether fractions were collected, washed twice with distilled water and dried over anhydrous sodium sulphate. The solvent was evaporated at $45^{\circ} \mathrm{C}$ using rotary evaporator. The residues were re-dissolved in $5 \mathrm{~mL}$ of HPLC-grade hexane. All samples were carried out in triplicates.

Statistical analysis: Bak All data was reported as mean \pm standard deviation (SD) of triplicate determination and analyzed using one-way analysis of variance (ANOVA) with significant differences between means determined at $p<0.05$, measured with Duncan's multiple range tests using Statistical Package for Social Science Research Version 15.0 (SPSS).

\section{RESULTS AND DISCUSSION}

The results of antioxidant vitamin levels in Bingol fresh pollen samples on June 2011 are summarized on Table-1. The results of antioxidant vitamin levels in samples of dried bee pollen and stored for eight months and their loss due to processing are summarized on Table-2.

TABLE-1

ANTIOXIDANT VITAMINS LEVELS IN BINGOL FRESH BEE POLLEN COLLECTED IN JUNE 2011

\begin{tabular}{cccc}
\hline $\begin{array}{c}\text { Pollen } \\
(\mathrm{n}=6)\end{array}$ & $\begin{array}{c}\text { Vitamin E } \\
(\mu \mathrm{g} / \mathrm{g})\end{array}$ & $\begin{array}{c}\text { Vitamin A } \\
(\mu \mathrm{g} / \mathrm{g})\end{array}$ & $\begin{array}{c}\text { Vitamin C } \\
(\mu \mathrm{g} / \mathrm{g})\end{array}$ \\
\hline Gökdere & $277.20 \pm 40.68^{\mathrm{a}}$ & $44.06 \pm 3.96^{\mathrm{a}}$ & $601.60 \pm 104.04^{\mathrm{a}}$ \\
Adaklı & $216.72 \pm 53.88^{\mathrm{abc}}$ & $34.00 \pm 1.56^{\mathrm{b}}$ & $455.66 \pm 48.60^{\mathrm{ab}}$ \\
Şirnan & $180.00 \pm 9.00^{\mathrm{b}}$ & $53.66 \pm 10.44^{\mathrm{a}}$ & $411.12 \pm 40.14^{\mathrm{b}}$ \\
Karlıva & $146.06 \pm 14.34^{\mathrm{c}}$ & $26.26 \pm 2.76^{\mathrm{c}}$ & $304.26 \pm 26.10^{\mathrm{c}}$ \\
Kanireş & $340.72 \pm 32.28^{\mathrm{a}}$ & $22.00 \pm 2.70^{\mathrm{a}}$ & $768.26 \pm 35.52^{\mathrm{a}}$ \\
\hline
\end{tabular}

Mean \pm standard deviation (SD). Each mean represents analyses of five independent samples. ${ }^{a, b, c, d}$ Variation in the following letters between samples indicates significant of difference by Duncan's test at $5 \%$ level $(p<0.05)$.

TABLE-2

ANTIOXIDANT VITAMINS LEVELS IN

SAMPLES OF DRIED BEE POLLEN COLLECTED AFTER EIGHT MONTHS OF STORAGE

\begin{tabular}{cccc}
\hline $\begin{array}{c}\text { Pollen } \\
(\mathrm{n}=6)\end{array}$ & $\begin{array}{c}\text { Vitamin } \mathrm{E} \\
(\mu \mathrm{g} / \mathrm{g})\end{array}$ & $\begin{array}{c}\text { Vitamin A } \\
(\mu \mathrm{g} / \mathrm{g})\end{array}$ & $\begin{array}{c}\text { Vitamin C } \\
(\mu \mathrm{g} / \mathrm{g})\end{array}$ \\
\hline Gökdere & $195.72 \pm 4.32^{\mathrm{a}}$ & $20.26 \pm 0.36^{\mathrm{a}}$ & $355.26 \pm 3.42^{\mathrm{a}}$ \\
Adaklı & $110.86 \pm 5.22^{\mathrm{b}}$ & $23.20 \pm 0.66^{\mathrm{b}}$ & $323.60 \pm 17.70^{\mathrm{abc}}$ \\
Şirnan & $142.60 \pm 4.74^{\mathrm{c}}$ & $33.13 \pm 0.60^{\mathrm{c}}$ & $240.26 \pm 51.06^{\mathrm{ab}}$ \\
Karlıva & $70.18 \pm 5.28^{\mathrm{d}}$ & $12.33 \pm 0.72^{\mathrm{d}}$ & $165.06 \pm 26.04^{\mathrm{a}}$ \\
Kanireş & $163.52 \pm 7.56^{\mathrm{e}}$ & $6.53 \pm 0.06^{\mathrm{e}}$ & $273.80 \pm 107.16^{\mathrm{a}}$ \\
\hline
\end{tabular}

Mean \pm standard deviation (SD). Each mean represents analyses of five independent samples. ${ }^{a, b, c, d}$ Variation in the following letters between samples indicates significant of difference by Duncan's test at $5 \%$ level $(p<0.05)$.

When the vitamin values of June and February were compared with each other, it was determined that, during this time, there was the maximum loss in the group Adakli with $68.23 \%$ in terms of vitamin $\mathrm{A}$, there was the maximum loss in the group Gökdere with $70.60 \%$ in terms of vitamin E, there was the maximum loss in the group Adakli with $71.01 \%$ in terms of vitamin $\mathrm{C}$. These results obtained about the values of vitamin may vary depending on the geographic location where the pollen grows up, the season in which it is gathered and its drying and storage conditions.

The concentration of vitamin $E$ in bee pollen ranged from 146.06-340.72 $\mu \mathrm{g} / \mathrm{g}$ in the fresh samples and from 70.18$195.72 \mu \mathrm{g} / \mathrm{g}$ in the processed samples. Different results were 
found by Oliveira ${ }^{15}$ ranging from $13.5-42.5 \mathrm{mg} / \mathrm{g}$ in the fresh samples and from 8.2-32.4 mg/g in the processed samples.

The concentration of vitamin $\mathrm{A}$ in bee pollen ranged from 22.00-53.66 $\mu \mathrm{g} / \mathrm{g}$ in the fresh samples and from 6.53-33.13 $\mu \mathrm{g} / \mathrm{g}$ in the processed samples. Different results were found by Almeida-Muradian ${ }^{16}$ ranging from 3.77-99.27 $\mu \mathrm{g} / \mathrm{g}$ in $\beta$ carotene the fresh samples and from 3.14-77.88 $\mu \mathrm{g} / \mathrm{g}$ in the processed samples. Because of $12 \mu \mathrm{g}$ of $\beta$-carotene is the same of a $1 \mu \mathrm{g}$ of retinol these samples is to equal $0.31-8.27 \mu \mathrm{g} / \mathrm{g}$ vitamin A the fresh samples and from $0.26-6.49 \mu \mathrm{g} / \mathrm{g}$ in the processed samples. Similarly, Oliveira ${ }^{15}$ showed values of vitamin A from 2.69-7.54 $\mu \mathrm{g} / \mathrm{g}$ (32.3 and $90.48 \mu \mathrm{g} / \mathrm{g} \beta$ carotene) processed samples.

The concentration of vitamin $\mathrm{C}$ in bee pollen ranged from 304.26-768.26 $\mu \mathrm{g} / \mathrm{g}$ in the fresh samples and from 165.06$355.26 \mu \mathrm{g} / \mathrm{g}$ in the processed samples. Different results were found by by Oliveira ${ }^{15}$ ranging from $273.9-560.3 \mu \mathrm{g} / \mathrm{g}$ in the fresh samples and from 152.8-542.2 $\mu \mathrm{g} / \mathrm{g}$ in the processed samples.

\section{Conclusion}

In this study, fresh pollens collected from Bingol were analyzed in June and the dried pollens stored by being kept in a cool, dark place for eight months at room temperature were analyzed again in February.

The differences were seen in this study for vitamin A, E and $\mathrm{C}$ content, between fresh bee pollens and dried bee pollens stored for eight months. These differences is explained by the climatic differences, the differences of blooming, different conditions of soil and botanical species and floral contributions that are inherent and specific to the region and period of the year in which the samples are collected. These factors may be related with the antioxidant levels of vitamins found in the fresh pollens groups. On the other hand, during the assessment of the contents of these vitamins in fresh pollen and after the process of drying, it was concluded that there was a loss of antioxidant vitamins (vitamin A, E and vitamin C) after the process of storage of pollens. This failure can be explained by their sensitivity to high temperatures which may have been used in the drying process of pollen pellets.

The contents of vitamins in pollen and other foods can suffer alterations with processing and storage. AlmeidaMuradian et al. ${ }^{3}$ in their analysis of samples $(\mathrm{n}=10)$ of dried bee pollen collected in the southern region of Brazil, observed the absence of $\beta$-carotene (pro-vitamin $\mathrm{A}$ ) and vitamin $\mathrm{C}$ (ascorbic acid). Barreto et al. ${ }^{17}$, while gathering information on package for preservation of dried bee pollen from seven different Brazilian states, studied expiry periods on the labels of packages ranging from six months to three years. Oliveira ${ }^{15}$ found superior results when she analyzed the content of vitamin $\mathrm{C}$ in samples of pollen $(n=10)$ that came from the town of Pindamonhangaba, São Paulo. The values were founded ranged from $273.9-560.3 \mathrm{mg} / \mathrm{g}$ in the fresh samples and from 152.8-542.2 $\mathrm{mg} / \mathrm{g}$ in the processed sample. It has been reported that in addition to the antioxidant vitamins $(C, E$ and $\beta$-carotene as pro-vitamin A) all of B-group vitamins, vitamin $\mathrm{D}$, proteins, carbohydrates, lipids and minerals exist in the pollen.

In the light of the results presented here, it can be concluded that there was statistically significant difference between fresh and processed samples, for vitamins. Loss of vitamins after bee pollen's storage at room temperature considerably increased. When considering the three conditions studied, the vitamin $\mathrm{E}$ appears to be better preserved during storage when compared to vitamin $\mathrm{C}$ and vitamin $\mathrm{A}$.

IDR for vitamin C is $90 \mathrm{mg} /$ day for man and $75 \mathrm{mg} /$ day for woman, than the samples collected in fresh bee pollen can be considered sources of vitamin $\mathrm{C}$ because they can provide between 7.60 and $19.20 \mathrm{mg}$ of this vitamin. And then the samples collected in dried bee pollen can be considered sources of vitamin $C$ because they can provide between 4.12 and 8.88 $\mathrm{mg}$ of this vitamin. IDR for vitamin A, IDR is $900 \mu \mathrm{g} / \mathrm{day}$ for man and $700 \mu \mathrm{g} /$ day for woman. Vitamin A value of the samples collected in fresh bee pollen 550 and $1341.5 \mu \mathrm{g}$ $(1.3415 \mathrm{mg})$, the value in dried bee pollen is between 163.25 and $828.25 \mu \mathrm{g}$ and it can be considered sources of vitamin A. IDR for vitamin $\mathrm{E}$ is $15 \mathrm{mg}$ /day for adults. Vitamin $\mathrm{E}$ value of the samples collected in fresh bee pollen $3.65 \mathrm{mg}$ and 8.51 $\mathrm{mg}$, the value in dried bee pollen is between $1.75 \mathrm{mg}$ and 4.89 $\mathrm{mg}$ it can be considered sources of vitamin $\mathrm{E}^{18}$.

\section{REFERENCES}

1. J.S. Bonvehi and R.E. Jorda, J. Agric. Food Chem., 45, 725 (1997).

2. G. Kroyer and N. Hegedus, Innov. Food Sci. Emerg. Technol., 2, 171 (2001).

3. L.B. Almeida-Muradian, L.C. Pamplona, S. Coimbra and O.M. Barth, J. Food Comp. Anal., 18, 105 (2005).

4. S.O. Wesh and R.M. Marston, Nutritional Bioavailability of Zinc, American Chemical Society, Washington D.C., USA (1983).

5. L.C. Marchini, V.D.A. Reis, A.C.C.C. Moreti, Em Piracicaba and Estado de São Paulo, Ciência Rural, Santa Maria, 36, 949 (2006).

6. S. Muniategui, M.T. Sancho, J. Lopez, J.F. Huidobro and J. Simal, J. Apicult. Res., 29, 147 (1990).

7. M.G. Campos, A. Cunha and K.R. Markham, In eds.: A. Mizrahi and Y. Lensky, Em Bee Pollen: Composition, Properties and Application, Plenum Press: New York, pp. 93-100 (1997).

8. N. Villamor and D. Colomer, Curr. Pharm. Design, 10, 841 (2004).

9. M.G. Campos, R.F. Webby, K.R. Markham, K.A. Mitchell and A.P. Cunha, J. Agric. Food Chem., 51, 742 (2003).

10. S. Kumazawa, T. Hamasaka and T. Nakayama, Food Chem., 84, 329 (2004).

11. B.A. Freeman and J.D. Crapo, Lab. Invest., 47, 412 (1982).

12. B. Halliwell, Lancet, 344, 721 (1994).

13. I. Amin and S.F. Cheah, Malaysian J. Nutr., 9, 31 (2003).

14. A.A. Abushita, E.A. Hebshi, H.G. Daood and P.A. Biacs, Food Chem., 60, 207 (1997).

15. K.C.L.S. Oliveira, Dissertação de Mestrado, Universidade de São Paulo, Brazil (2006).

16. L.B. de Almeida-Muradian, Quim. Nova, 33, 514 (2010).

17. L.M.R.C. Barreto, S.R.C. Funari and R.O. Orsi, Boletim de Indústria Anim., 62, 167 (2005).

18. http://books.nap.edu/books//jbcs, accessed December (2008). 